\title{
Biotechnology, Patents and Morality
}

This book critiques the decision-making process in Article 53(a) of the European Patent Convention. To date, such decisions have been taken at high levels of expertise without much public involvement. The book eschews traditional solutions, such as those found within legislative, judicial and patent office realms and instead develops a radical blueprint for how these decisions can be put to the public. By examining wide-scale models of participatory democracy and deliberation, this book fills a significant gap in the literature. It will be invaluable for patent lawyers, academics, practitioners and intellectual property and patent officials.

Maureen O'Sullivan, BA, BCL, LLM, PhD. Lecturer (Above the Bar) in Law, National University of Ireland, Galway. Chair, Vegetarian Society of Ireland. Fellow, Oxford Centre for Animal Ethics. 


\section{Routledge Research in Intellectual Property}

Available:

Well-Known Trade Marks

A Comparative Study of Japan and the EU

Hiroko Onishi

Contemporary Issues in Pharmaceutical Patent Law

Setting the Framework and Exploring Policy Options

Bryan Mercurio and Daria Kim

Intellectual Property, Finance and Corporate Governance Janice Denoncourt

Protecting Intellectual Property in the Arabian Peninsula The GCC States, Jordan and Yemen

David Price and Alhanoof AlDebasi

Biodiversity, Genetic Resources and Intellectual Property Developments in Access and Benefit Sharing

Charles Lawson and Kamalesh Adhikari

Pharmaceutical Patent Protection and World Trade Law The Unresolved Problem of Access to Medicines Jae Sundaram

Patent Pools, Competition Law and Biotechnology

Devdatta Malshe

Copyright Law and Derivative Works

Regulating Creativity

Omri Rachum-Twaig

The Patentability of Software

Software as Mathematics

Anton Hughts 


\section{Biotechnology, Patents and Morality}

A Deliberative and Participatory Paradigm for Reform

\section{Maureen O'Sullivan}


First published 2020

by Routledge

2 Park Square, Milton Park, Abingdon, Oxon OXI4 4RN

and by Routledge

52 Vanderbilt Avenue, New York, NY 10017

Routledge is an imprint of the Taylor \& Francis Group, an informa business

(C) 2020 Maureen O'Sullivan

The right of Maureen O'Sullivan to be identified as author of this work has been asserted by her in accordance with sections 77 and 78 of the Copyright, Designs and Patents Act 1988.

All rights reserved. No part of this book may be reprinted or reproduced or utilised in any form or by any electronic, mechanical, or other means, now known or hereafter invented, including photocopying and recording, or in any information storage or retrieval system, without permission in writing from the publishers.

Trademark notice: Product or corporate names may be trademarks or registered trademarks, and are used only for identification and explanation without intent to infringe.

\section{British Library Cataloguing in Publication Data}

A catalogue record for this book is available from the British Library

\section{Library of Congress Cataloging-in-Publication Data}

Names: O'Sullivan, Maureen, 1967- author.

Title: Biotechnology, patents and morality : a deliberative and participatory paradigm for reform / by Maureen O'Sullivan.

Description: Abingdon, Oxon ; New York, NY : Routledge, 2019.

Series: Routledge research in intellectual property | Based on author's thesis (doctoral - University of Edinburgh, 2018) issued under title: Morality patently matters : the case for a universal suffrage for morally controversial biotechnological patents. | Includes bibliographical references and index.

Identifiers: LCCN 2019013033 | ISBN 9780367181246

Subjects: LCSH: Biotechnology--Europe--Patents. | Patent laws and legislation--Moral and ethical aspects. | European Patent Convention (1973 October 5 )

Classification: LCC KJC2751.B56 O88 2019 | DDC 346.404/68--dc23

LC record available at https://lccn.loc.gov/2019013033

ISBN: 978-0-367-18124-6 (hbk)

ISBN: 978-0-367-18127-7 (ebk)

Typeset in Galliard

by Taylor \& Francis Books 
This book is dedicated to Ciara, Conor and Randall, in line with a longstanding promise - and Isaac. 
$\Longrightarrow$ Taylor \& Francis

Taylor \& Francis Group

http://taylorandfrancis.com 


\section{Contents}

Table of cases $\quad x$

Table of legislation xii

Acknowledgements xiii

General introduction 1

Brief introduction to the European patent system 1

The emergence of morality and its inclusion in European patent law 1

A tripartite nexus: biotech comes of age, patents proliferate and morality matures 2

Outstanding disquiet: who gets to decide and how? 3

A participatory paradigm for deliberative decisions 5

1 In search of a definition of morality in European Patent Law

1.1 Introduction 6

1.1.2 Origins of patent law and its evolution until present times 7

1.1.3 Patent requirements 8

1.2 National to International Coverage: changes in protection in both form and substance 9

1.2.1 The Paris Convention for the Protection of Industrial Property 18839

1.2.2 Universal Declaration of Human Rights 194810

1.2.3 Strasbourg Convention 1963 - an optional morality provision 11

1.2.4 Patent Cooperation Treaty (PCT) 197011

1.2.5 European Patent Convention 1973 - morality mandated 11

1.2.6 Trade Related Aspects of Intellectual Property Rights (TRIPS) 199418 
1.2.7 Directive 98/44/EC on the legal protection of biotechnological inventions 19

1.2.8 Amendment to EPC 200027

1.2.9 Patent Law Treaty 200028

1.2.10 An EU-wide patent 28

1.2.10.1 Precursors 28

1.2.10.2 Unitary Patent Protection 29

1.3 European case law on morality and ordre public 31

1.3.1 At the EPO 31

1.3.2 The drafting intentions of the EPC 31

1.3.3 Morality in the case law of the CJEU 46

1.3.4 Conclusion 51

2 Patent moralities and their traditional adjudications: A critique

2.1 Introduction 52

2.2 Untangling morality of the invention and morality in patent grants 54

2.2.1 Can morality provisions in patent law just be ignored? 57

2.2.2 Opposition on morality grounds: public voices 60

2.2.3 Traditional methods of reform 64

2.3 Would specialised courts better address the issue of morality? 64

2.3.1 The US 64

2.3.2 Europe 66

2.4 Legislative clarity 67

2.5 Reform through the patent/intellectual property office 72

2.6 Ethics committees 76

2.6.1 National committees 80

2.6.2 Other committees 83

2.7 Conclusion 83

3 Decision-making in morally controversial biotechnological patent applications

3.1 Introduction 85

3.2 Academic calls for more public involvement in biotech patents 85

3.3 Different ways to facilitate public involvement 87

3.4 Participation defined 89

3.4.1 The human right to participate 89

3.4.2 A United Nations framework for participation 92

3.4.3 Participation as a reform mechanism? 93

3.5 Deliberative democracy and its rationale defined 95

3.5.1 The nature of deliberation: confrontation or comprehending? 98 
3.5.2 Classes of deliberative democracy: elitist or populist? 100

3.5.3 Early and meaningful input 104

3.5.4 Deliberative devices and scale 107

3.5.5 Government oversight 110

3.5.6 Education of the citizenry and inclusion 112

3.5.7 Location of debate and expert bodies 116

3.6 Conclusion 120

4 The participatory budget in Brazil

4.1 Introduction 121

4.2 Participatory and representative democracy: some general points 122

4.2.1 Background to the participatory budget 123

4.2.2 The participatory budget and how it operates 125

4.2.3 Increase in scope of issues and political organisation 128

4.2.4 Obligatory participation or encouragement to participate? 129

4.2.5 Education and educating the educators 132

4.2.6 Quasi-legality or legislation? 135

4.2.7 Effect on civic life of participation 138

4.2.8 The role of the state in approximating representation to participation 139

4.2.9 Global recognition and transplantability 140

4.3 Principles of participation for patent reform 142

4.4 Conclusion 143

5 Recommendations for reform and conclusion

5.1 Introduction 144

5.2 Proposed structure of a universal patent suffrage at the EPO 145

5.2.1 Phase one 145

5.2.2 Phase two 146

5.2.3 Phase three 148

5.3 A model for public education on technology-related issues 149

5.3.1 Does education about science present specific challenges? 150

5.3.2 The participatory right in morally controversial patents 151

5.4 Objections 152

5.5 Conclusion 156

Index 


\section{Table of cases}

$A$ \& P TEA CO v Supermarket Corp, 340 US 147, 71 S Ct 127, 95 L Ed 162 (1950), 65

Animal Legal Defense Fund v Quigg (1991) 932 F 2d 920 (Court of Appeals, Federal Circuit), 63

Arizona State Legislature v Arizona Independent Redistricting Commission, 576 US, 135 S Ct 2652 (2015), 88

Association for Molecular Pathology v Myriad Genetics, Inc (2012) 132 Ct 1794 (Supreme Court), 23

C-34/10 Oliver Brïstle v Greenpeace eV [2011] -09821 (Grand Chamber), 24, $27,43,46,47,48,49,53,57,59,68,76,100,104,119,133,148$

C-364/13 International Stem Cell Corporation v Comptroller General of Patents EU:C:2014:2451, 24, 43, 49, 53, 59, 148

C-377/98 Netherlands v Parliament and Council [2001] ECR 1-070709 (ECJ), 20,73

C-377/98 The Kingdom of the Netherlands $v$ European Parliament and Council [2002] FSR 36, 20

C456-03 Commission v Italy [2005] ECR -5335, 26

Ciba-Geigy/Propagating Material (1979) C EPOR, 21

Diamond v Chakrabarty (1980) 447 US 303 (Supreme Court), 21, 23, 53, 55, $65,70,121$

Edinburgh Patent Application No 949131742 (EPO Opposition Division), 24, 38, $56,58,77,100$

G2/06 (Use of embryos/WARF) (OJ EPO 2009, 306), 12, 17, 39, 40, 42, 43, 46, $59,61,76,104,133,135,154$

G2/12 ("Tomatoes") and G2/13 ("Broccoli II") on 25 March 2015, OJ EPO 2016,22

Harvard/Onco-Mouse [1989] OJ EPO 451, 32

Harvard/Onco-Mouse [1991] EPOR 525, 8, 25, 33

Howard Florey Institute-Relaxin [1995] 6 OJ EPO 388 (EPO Opposition Division), 31, 87

In the matter for an application for a patent by $A$ and $H$ [1927] 44 RPC 298, 14

In the Matter of an application for a patent by Rufus Riddlesbarger [1935] 53

RPC 57, 14 
Juicy Whip, Inc v Orange Bang, Inc (1999) 185 F 3d 1364, 58

Leland/Stanford Modified Animal [2002] EPOR 2, 34

Lowell v Lewis, 15 F. Cas. 1018 (1817), 40, 58, 65

Lubrizol/Hybrid Plants [1990] EPOR 173, 21, 31, 32

McKenna v An Taoiseach [1995] Ir Rep 10, 147, 155

Monsanto Technology LLC v Cefetra BV and Others [2010] ECR I 6765, 26

Moore $v$ Regents of University of California (1990) 793 P 2d 479, 23, 121

Plant Genetic Systems NV v Greenpeace Ltd [1995] EPOR 357, 3, 26, 35, 36, 44, 61, 74, 10, 104, 119

$R v$ Ministry of Agriculture, Fisheries and Food ex p Compassion in World Farming

Ltd (Case C-1/96) [1998] All ER (EC) 302, 70

Re Upjohn's Application, Case No. 89913146.0., 34, 61

ShopalottoCom Ltd, Re Patent Application GB 00177725 [2005] EWHC 2416, 13

T-1173/97 Computer program product/IBM [1999] OJ EPO 609, 13

T1374/04 WARF/Stem Cells [2006] EPOR 31, 39

T 0149/11 of 24.1.2013, Method and Device for Processing a Slaughtered Animal or Part Thereof in a Slaughterhouse, 28, 45

T 0315/03 (Transgenic Animals/HARVARD) of 6.7.2004, 25, 34, 44, 74, 104, 119

T 2221/10 (Culturing Stem Cells/TECHNION) (2014), 42, 43, 154

Visx Inc v Nidek Co Ltd and others (No 2) [1999] FSR 405, 7 


\section{Table of legislation}

Agreement on a Unified Patent Court and Statute of the Unified Patent Court 2013,30

Charter of Fundamental Rights of the European Union 2000, 10, 26, 34, 38, 45, $46,48,59$

Community Patent Convention 1975, 29

Directive $98 / 44 / \mathrm{EC}$ on the legal protection of biotechnological inventions, vii, 19, see also Biotech Directive, 12, 20, 24, 27, 28, 30, 38, 46, 49, 51, 53, 56, $57,58,63,68,69,70,73,77,78,81,136,146,154,155$

European Convention on Human Rights 1950, 10, 34, 45, 48, 49, 59, 154

European Patent Convention 2000, i, 1, 7, 11, 12, 25, 42, 52, 61, 85, 121, 145

Leahy-Smith America Invents Act 2011, 9, 24, 70

Paris Convention for the Protection of Industrial Property (1883), vii, 9

Patent Cooperation Treaty 1970, 1, 11

Patent Law Treaty 2000, vii, 28

Patents, Designs and Trade Marks Act 1883, 14

Regulation (EU) No 1257/2012 of the European Parliament and of the Council of 17 December 2012 implementing enhanced cooperation in the area of the creation of unitary patent protection, 29

Statute of Monopolies 1624, 8

Strasbourg Convention 1963, vii, 1, 11

Trade Related Aspects of Intellectual Property Rights 1994, vii, 1, 18, 58

Universal Declaration on Bioethics and Human Rights 2005, 56, 76, 79, 88, 92, 153

Universal Declaration of Human Rights 1948, vii, 4, 10, 89, 92, 153

Vienna Convention on the Law of Treaties 1969, 12 


\section{Acknowledgements}

This book is based on my doctoral research for which I was blessed with two outstanding supervisors, Professor Graeme Laurie and Mr. Gerard Porter, both at the University of Edinburgh. Without their excellent guidance and advice, this work may not have been achieved. 
$\Longrightarrow$ Taylor \& Francis

Taylor \& Francis Group

http://taylorandfrancis.com 


\section{General introduction}

\section{Brief introduction to the European patent system}

European patent law is intricate and multifaceted. Inventors have a dizzying array of jurisdictions from which to choose to protect their inventions. Patents can be granted by the European Patent Office under the European Patent Convention (EPC). Patents can be applied for in Geneva under the Patent Cooperation Treaty (PCT), which is an international treaty. Applicants can seek patents at national level and applications for EPC or PCT patents can be made at the national offices too. The latter can also be applied for at the European Patent Office (EPO).

At EU level, the Biotechnology Directive regulates some of the finer points of national patents when cases in which an interpretation of the Directive is sought are referred from national courts. At present there is no EU-wide patent but there is an agreement in place to introduce this protection at EU level under the EPC, creating a different jurisdiction. This is complicated somewhat by the fact that not all states have agreed to be a part of the patent system. Moreover, the establishment of the court system has proved contentious. By way of comparison with other jurisdictions that do not have multiple linguistic challenges, the European patent system appears to be ever more complex. All these procedural matters will be examined at the beginning of the book.

\section{The emergence of morality and its inclusion in European patent law}

In addition to these elaborate bureaucratic issues, the substantive law in Europe places a morality bar on controversial inventions - a prohibition which does not exist in other jurisdictions such as the US. Since the advent of biotechnology, this has assumed greater importance as the Boards and Courts have to deal with inventions which involve commodification of living matter or, indeed, destruction of human embryos.

The first European legislative instrument to broach the issue of morality predated the founding of the European Economic Community (EEC) and was embodied in the Strasbourg Convention which made morality an optional exception. When the EPC superseded the Strasbourg Convention this morality bar was made mandatory. Morality provisions have been included since then in both the Trade Related Aspects of Intellectual Property Rights (TRIPS) Agreement and the 


\section{General introduction}

EU Biotechnology Directive. Its meaning is somewhat obscure as legislators declined to endeavour to define morality leaving it instead to European institutions to debate. Morality, before the age of biotechnology tended to be invoked to restrict patents on gambling machines or abortifacients. The discovery of the DNA helix gave scientists the tools to start experimenting with genetic material and in order to fund their research and to profit from it they sought - and were granted - patents on these inventions.

Patent officials, asked to rule on morality when their expertise is in technical matters, arguably need a model which will assist them in the process through which they currently seem to muddle. Moreover, concepts of morality differ greatly across Europe. ${ }^{1}$ This book focuses on this problem and seeks a resolution.

\section{A tripartite nexus: biotech comes of age, patents proliferate and morality matures}

As biotechnology developed, more and more patents were sought and granted amid controversies that life itself was being commoditised. Inventions which were sometimes more akin to discoveries also benefited from patent protection. The legal regime was more liberal in the US than in Europe because of the absence of a statutory morality bar in the former's patent legislation.

As noted, the EPC provides a morality bar for inventions that are otherwise patentable. If such inventions are within the morality exceptions, a patent cannot be granted. Yet there is no definition of morality which can guide patent officials who are obliged to apply it. Nor do the Boards of the EPO have a handbook to enlighten them. Currently, the case law does not predict how morality will be defined, as judges have little to guide them. In any case, morality by its nature evokes much disagreement, societal standards change over time and as a result of technological developments. How should issues relating to the morality bar, when a patent could be granted because the criteria are fulfilled but the invention potentially falls foul of Article 53(a) of the EPC, be decided? Article 53(a) provides that the invention must not offend against morality (or ordre public). The EPO has been criticised for not having achieved a satisfactory way of resolving this question. $^{2}$

The application of the morality bar is thus problematic in terms of how this is decided and by whom. As everyone's conception of morality in a pluralistic world is likely to vary, an effective way of arbitrating between such potential polarities is important. Where decision-making is perceived by some critics as lacking in legitimacy as is the case in the interpretation of morality, much time will be spent in challenges to patent grants or revocations which could be avoided if such

1 This was acknowledged in the 'Travaux Préparatoires (EPC 1973)', IV/2767/61-E, 7, http://webserv.epo.org/projects/babylon/tpepc73.nsf/0/A79664CCCE197AClC125 7427004 (accessed 5 March 2019).

2 Amanda Warren-Jones, 'Identifying European Moral Consensus: Why Are the Patent Courts Reticent to Accept Empirical Evidence in Resolving Biotechnological Cases?' (2006) 28 EIPR 26. 
processes were not so contentious from the start. This greatly increases potential cost of the patenting system too.

There is, of course, some academic support for the abolition or disregard of the morality bar but such a proposition is not advocated in this book. Rather, the focus of this work is on critiquing the existing decision-making process and recommending the adoption of an alternative - a blueprint which will be designed and discussed as the work progresses.

\section{Outstanding disquiet: who gets to decide and how?}

Traditionally, our legislators made important decisions for us in representative democracies but in an increasingly complex technological arena, patent officials determine whether biotechnological inventions are moral or immoral. This raises questions as to the quality of their decisions as there is no indication as to how they are qualified for such a task, nor do they have a set of principles which highlights the sort of inventions that would be subject to such scrutiny. Moreover, judges in early case law, such as Plant Genetic Systems, ${ }^{3}$ were dismissive of some structures of public input such as opinion polls and surveys but the same courts did not outline how public opinion could be accommodated and hence excluded it.

The decision-making process for morally controversial biotechnological patent applications under Article 53(a) EPC is somewhat arbitrary as patent officials have to take decisions without guidance. Would judges, legislators or ethics committees be better suited to this task? As morality is a matter of societal-wide concern, the publics should have an input into such decisions, this work contends. This is especially important given the promise that patentable biotechnological inventions hold for curing disease, for instance, which is a matter of interest to us all.

Engagement on the issue of public debate is not currently being addressed because the EPO tends only to name what is not an acceptable way of listening to public concern. ${ }^{4}$ Devices which seek to elicit public views such as opinion polls and surveys have not been accepted as evidence by the EPO. ${ }^{5}$ The EPO tends to negate efforts by non-governmental organisations (NGO) to involve public voices; ${ }^{6}$ perhaps rightly so. NGOs may not be better placed to elicit public views than officials at the EPO.

Arguably, the EPO already has a participatory process in that patent grants can be opposed and the opposition proceedings do allow individual representation. Controversial or unpopular decisions can therefore be contested but accessibility and deliberation fall somewhat short in this paradigm. This process is not adequate to address the normative claim of this book that when morality provisions are engaged by patent applications, public voices should be solicited, in a different way. This book examines a variety of possible solutions to the EPO's decision-

$3 \quad$ Plant Genetic Systems v Greenpeace [1995] EPOR 357.

4 Plant Genetic Systems v Greenpeace [1995] EPOR 357, 368-369.

5 Ibid.

6 Ibid. 


\section{General introduction}

making process, including judicial, legislative, patent office reform and the establishment of ethics committees.

None of these models of reform would achieve the wide-scale deliberation and participation that this work seeks to establish. There is some academic literature in which lawyers with expertise in the patenting of biotechnological inventions call for more public involvement and more transparency in the arbitration of this aspect of morality. This work develops a model of how the publics can be involved in ways that are meaningful in terms of the decision-making process.

This book does not advocate the harvesting of ill-informed public opinions. Instead, it will build a case to argue that when the morality bar in the EPC in the form of Article 53(a) EPC is engaged, the EPO should, instead of making unpredictable decisions behind closed doors which then may be challenged by a laborious number of processes, open the decision to education, deliberation and a subsequent vote. This process will elicit views from the 38 states $^{7}$ of the EPO. This draws on the approach pioneered in several Latin American countries which have established large-scale participatory democratic models. These involve frequent, direct votes on budgets and when those involved lack practical knowledge and education in the subject-matter at hand, local governments pay for their tuition and so equip them with the necessary skills. This book does not compare budgets and biotechnological inventions but, rather, gleans principles from participatory practices and seeks to apply them to certain EPO decision-making processes.

We currently lack a documented, functioning, adjusted and long-lived paradigm for the manner in which the patent system's decision-making process in the area of morality in biotechnological inventions can be opened up to public education, deliberation, participation and a vote. This is important because there is a body of thought which suggests that more democracy is desirable in this realm but does not develop this aspirational claim by showing how participation and deliberation can be combined in a complimentary fashion. The participatory budget has been able to adapt to changing circumstances on many occasions due to the flexibility of its participants and structure.

While it might be somewhat unorthodox to go to the Global South in search of a model of democratic innovation, the political climate in which participatory models of democracy emerged in Latin America features certain factors which may have been missing in Europe when democracy was first extended. At first sight what appears unconventional, at second sight may became logical and, indeed, modern. In Latin America, many recent constitutions enshrine participatory rights as they were gestated within a pre-existing international human rights framework. This contrasts with the formative period of other constitutions which were drafted within the nation state prior to the Universal Declaration of Human Rights and where the right to participate had not received consideration. The outer remit of what nowadays are regarded as human rights has expanded notably and has been influenced by international and regional bodies' declarations and conventions, activist judiciaries and socially minded legislatures.

7 Correct as of 5 March 2019: https://www.epo.org/about-us/organisation/mem ber-states.html (accessed 5 March 2019). 


\section{A participatory paradigm for deliberative decisions}

The right to participate is now identified as a human right and if meaningful public involvement is to be achieved, deliberation and participation should be combined. This may facilitate meaningful societal input. It is argued that in order to allay public concerns and to assist the EPO's duty as a public body to reach legitimate decisions, a much more robust and large-scale model is preferable to piecemeal, ad hoc paradigms.

The book will extract abstract principles from the participatory budget for reform of the decision-making process at the EPO. Features that can be generalised from the budget to the patent system are the Executive's role or potential role in organising and facilitating debate among the general public. Constructive deliberation and participation do not appear to spring up from grassroots levels spontaneously. In fact, mediation is important; otherwise debate can be fraught, polarising and can foster ill-will. The book will link the theoretical work on best practice in deliberation with the case study of the participatory budget. This will be in order to design a model for patent office reform in the fraught area of morally controversial biotechnological patents.

This book sketches a model for how a public awareness and educational campaign on issues of morality in biotechnological patent applications can be carried out. It also gives an example of how the publics can be involved and engaged widely through the use of outreach staff so that they not only deliberate but are also incentivised to participate. It will apply the principles from the discussions on deliberation and participation to aid in the drafting of a model of how participatory patents along with a plebiscite can be fashioned. It will also address some potential objections but will conclude showing that these can be addressed constructively and that an inclusive patenting system where issues of morality arise can be created.

While patent grants do require technical and legal skills, considerations of morality are potentially of interest to everyone. Even if publics are disinterested, the opportunity to participate should nonetheless be available as is the right to participate in referendums or, indeed, the right to vote. Expertise in scientific or regulatory matters does not mean expertise in ethical issues and at the level of ethics or morality, all views should receive equal airing, it will be contended.

It is argued that whenever the morality clause in Article 53(a) EPC is invoked a direct vote or type of referendum should be in place whereby the publics can decide whether the patent should or should not be granted. The EPO, as a public body, may actually be better placed to manage the practicalities and cost of organising such deliberative and participatory practices than a random array of special interest groups for whom the logistics (in terms of cost, time, travel and so on) may prohibit participation in opposition and appeals proceedings.

Radical reform of the triumvirate of patents, biotechnology and morality is currently untouched and this book makes an argument for a universal patent suffrage based on participatory practices which are explored to move beyond the theoretical to the practical. It therefore makes a contribution to knowledge in this area and fills a gap in the literature. 